ORIGINAL ARTICLE

\title{
Health Related Quality of Life Among Coronary Artery Bypass Graft Patient Attended at Combined Military Hospital, Dhaka
}

\author{
*SMN Irfan ${ }^{1}$, M Rahaman ${ }^{2}$, A Noman ${ }^{3}$, S Mithun ${ }^{4}$ \\ ${ }^{1}$ Major (Dr) SM Nurul Irfan, Student Officer, MPH (HM), Armed Forces Medical Institute, Dhaka \\ ${ }^{2}$ Colonel (Dr) Md Mahbubur Rahaman, Officers Training, Armed Forces Medical Institute, Dhaka \\ ${ }^{3}$ Lt.Colonel (Dr) Abu Noman Md Mosleh Uddin, Instructor Medicine, Armed Forces Medical Institute, Dhaka \\ ${ }^{4}$ Major (Dr.) Sangita Mithun, Assistant professor, Department of Physiology, Armed Forces Medical College, Dhaka \\ *Corresponding author
}

\begin{abstract}
This descriptive type of cross sectional study was carried out among purposively selected 90 coronary artery bypass graft operated patients attended at cardiovascular surgery out patient department of combined military hospital, Dhaka from 01 March 2012 to 30 June 2012 with the objective to assess the quality of life by using the RAND Medical Outcomes Short Form 36 (SF36) questionnaire. The population studied had a mean age of 54.60 years with $92.2 \%$ were male and $7.8 \%$ were female. Most of the respondents were retired $(43.3 \%)$ followed by service personnel (38.9\%). Regarding educational qualification, most of them were between class VIII to SSC and $95.6 \%$ were Muslim. The mean monthly income of the respondents was Tk. 18127.78. The findings showed that post CABG respondents possessed a good level of QOL with an average score of 86.0921 . The mental components score $(87.8571)$ was found to be higher than physical component score (84.9153). It was found that the association between age and physical functioning domain of physical component was statistically significant $\left(\mathrm{r}=-.189^{*}\right.$, $\mathrm{p}<0.05$ ) and association between all other domains (role physical, bodily pain, general health, vitality, social functioning, role emotional and mental health) were statistically not significant. The study also revealed a negative correlation of total quality of life with age but positive correlation with other socio demographic characteristics (level of income, education and occupation) though all of the relations were statistically not significant. No statistically significant difference revealed with the different domains of quality of life and socio demographic characteristics. In regards to the monthly income, highest score noted in Tk. 10000-30000 income groups in all the domains. Respondents' occupation showed significant difference with the general health domain $(\mathrm{F}=3.456, \mathrm{p}<0.05)$ and physical component summary $(\mathrm{F}=2.969, \mathrm{p}<0.05)$ of the SF- 36 items. The education level showed significant difference with the physical functioning of physical component domain $(F=2.675, p<0.05)$. The findings showed that the highest score was for HSC education in both the components of quality of life. The post CABG respondents possessed a good level of QOL with good mental components score than physical component score. It is also revealed from the study that with increasing age the physical functioning of the patient decreases. From the study it depicts that higher education, better occupation and good monthly income of the respondents have better quality of life out come than that of others. Study on larger sample size may be carried out for more accurate results on quality of life after CABG operation.
\end{abstract}

\section{Introduction}

Coronary artery disease (CAD) is among the leading cause of death for both men and women in the Bangladesh. According to the World Health Organization (WHO) out of 34 million deaths from non-communicable diseases, CAD

causes 27\% deaths in 2008 in Bangladesh. CVDs are the number one cause of death globally: more people die annually from CVDs than from any other cause. An estimated 17.3 million people died from CVDs in 2008,

AKMMC J 2013; 4(2): 10-17 
SMN Irfan, M Rahman, A Noman et al

representing $30 \%$ of all global deaths. Of these deaths, an estimated 7.3 million were due to coronary heart disease and 6.2 million were due to stroke. Low- and middle-income countries are disproportionally affected: over $80 \%$ of CVD deaths take place in low- and middle-income countries and occur almost equally in men and women. By 2030, almost 23.6 million people will die from CVDs, mainly from heart disease and stroke. These are projected to remain the single leading causes of death ${ }^{1}$.

One surgical intervention available for the treatment of CAD is coronary artery bypass grafting (CABG). CABG is used to restore the heart muscle with blood and oxygen via arteries and veins taken from elsewhere in the body, typically the arms, legs, or mammary ${ }^{2}$. The atheromatous arteries are replaced by open vessels from other arterial or venous sites in the body. CABG is the primary treatment option for the coronary artery disease and improvements in survival and quality of life are the primary indications for the operation. It is important to consider that the operation relieves the symptoms of cardiac disease and this reduction does not directly translate into quality of life improvement following surgery. The operation has an impact on over all physical and mental health status and quality of life. More than 4,000 CABG procedures take place each year in Bangladesh ${ }^{3}$. Also a good number of patients travelled abroad for CABG operation especially at India, Singapore, Bangkok etc. According to the AHA (2004) task force on practice guidelines, the guidelines for the CABG surgery include: extensive coronary artery disease, future reduction of angina, survival statistics, and quality of life improvement ${ }^{4}$. It is the practitioners' responsibility to evaluate the quality of life as an integral part of an assessment for long-term post CABG outcomes in order to assess the medical necessity for $\mathrm{CABG}^{5}$.

The World Health Organization defines quality of life (QoL) as 'an individual's perception of their position in life in the context of the culture and value systems in which they live and in relation to their goals, expectations, standards and concerns'. It has been demonstrated that the risk factors for coronary artery disease (CAD) influence QoL, and a reduction in exposure to these risk factors would imply lengthening of life and improved health-related QoL in patients. Several instruments are available to assess changes in QOL over the course of treatment, especially in patients with coronary artery disease (CAD). The Short Form Health Survey (SF-36) questionnaire is one of the most widely generic health status instruments used extensively in cardiac patient populations ${ }^{6}$.

\section{Materials and Methods}

The Medical Outcomes Short Form 36 (SF-36) as general health status consisted of 36 multiplechoice questions sorted into two components: physical component summary (PCS) and mental component summary (MCS). It comprised of eight assessment scales: 1) physical functioning measures the limitations in physical activity due to health problems; 2) role physical items identify limitations in usual role activities because of physical health problems; 3) bodily pain items to assess presence of pain and limitations due to pain; 4) general medical health include self evaluation of health; 5) vitality items to assess energy and fatigue levels of the respondents. 6) role limitation measures the limitations in usual role activities because of emotional problems; 7) social functioning measures the limitation of social activities because of physical and emotional problems; 8) mental health items measures psychological distress and well-being. These domains were used to measure the QOL in post CABG patients at $\mathrm{CMH}$, Dhaka. Socio-demographic data including age, sex, religion, marital status, education level, occupation, monthly income, family size in the study. The inclusion criteria includes all patients of coronary artery bypass graft operation attended at cardiovascular surgery out patient department of CMH, Dhaka three months or more after the operation who on agreed to sign a written consent. A total of 90 post $\mathrm{CABG}$ patients at $\mathrm{CMH}$, Dhaka, were recruited purposively in this study. Basing on The Medical Outcomes Short Form 36 (SF-36), a semi-structured and interviewer administered questionnaire was developed for data collection. 
Health Related Quality of Life Among Coronary Artery Bypass After data collection the responses of the responded were analyzed following general guideline of SF-36 scoring instructions which are shown below. Statistical Package for Social Science (SPSS) 19 for Windows was used for statistical analyses. Descriptive analyses include frequency of the respondents' sociodemographic, mean and standard deviation on the score of QOL. Inferential analysis such as Analysis of Variance (ANOVA) test was used to compare the relationship between sociodemographic data and QOL of the post CABG respondents. $\mathrm{P}$ value $<0.05$ was accepted as level of significance.

Scoring and analysis guideline of the questionnaire

\begin{tabular}{|c|c|c|c|c|}
\hline Scale & $\begin{array}{l}\text { No of } \\
\text { Items }\end{array}$ & $\begin{array}{l}\text { Original } \\
\text { responses }\end{array}$ & Recorded valu & Remarks \\
\hline \multirow[t]{3}{*}{ Physical functionin } & \multirow[t]{3}{*}{10} & 1 & 0 & \\
\hline & & 2 & 50 & \\
\hline & & 3 & 100 & \\
\hline \multirow{2}{*}{$\begin{array}{l}\text { Role limitations due } \\
\text { physical health }\end{array}$} & \multirow[t]{2}{*}{4} & 1 & 0 & \\
\hline & & 2 & 100 & \\
\hline \multirow{2}{*}{$\begin{array}{l}\text { Role limitations due } \\
\text { emotional problems }\end{array}$} & \multirow[t]{2}{*}{3} & 1 & 0 & \\
\hline & & 2 & 100 & \\
\hline \multirow[t]{6}{*}{ Energy/ fatigue } & \multirow[t]{6}{*}{4} & 1 & $100 / 00$ & \multirow{6}{*}{$\begin{array}{l}\text { Out of } 4 \text { questions, } \\
2 \text { questions score in } \\
\text { ascending order, } 2 \text { in } \\
\text { descending order }\end{array}$} \\
\hline & & 2 & $80 / 20$ & \\
\hline & & 3 & $60 / 40$ & \\
\hline & & 4 & $40 / 60$ & \\
\hline & & 5 & $20 / 80$ & \\
\hline & & 6 & $00 / 100$ & \\
\hline \multirow[t]{6}{*}{ Emotionall being } & \multirow[t]{6}{*}{5} & 1 & $100 / 00$ & \multirow{6}{*}{$\begin{array}{l}3 \text { questions score in } \\
\text { ascending order, } 2 \text { in } \\
\text { descending order }\end{array}$} \\
\hline & & 2 & $80 / 20$ & \\
\hline & & 3 & $60 / 40$ & \\
\hline & & 4 & $40 / 60$ & \\
\hline & & 5 & $20 / 80$ & \\
\hline & & 6 & $00 / 100$ & \\
\hline \multirow[t]{5}{*}{ Social functioning } & \multirow[t]{5}{*}{2} & 1 & $100 / 00$ & \multirow{5}{*}{$\begin{array}{l}1 \text { question in descend } \\
\text { and another one is } \\
\text { ascending order }\end{array}$} \\
\hline & & 2 & $75 / 25$ & \\
\hline & & 3 & $50 / 8$ & \\
\hline & & 4 & $25 / 75$ & \\
\hline & & 5 & $00 / 100$ & \\
\hline \multirow[t]{5}{*}{ Pain } & \multirow[t]{5}{*}{2} & 1 & $100 / 00$ & \multirow{5}{*}{$\begin{array}{l}1 \text { question in descend } \\
\text { and another one is } \\
\text { ascending order }\end{array}$} \\
\hline & & 2 & $75 / 25$ & \\
\hline & & 3 & $50 / 50$ & \\
\hline & & 4 & $25 / 75$ & \\
\hline & & 5 & $00 / 100$ & \\
\hline \multirow[t]{5}{*}{ General health } & \multirow[t]{5}{*}{5} & 1 & $100 / 00$ & \multirow{5}{*}{$\begin{array}{l}2 \text { question in descend } \\
\text { and three in ascendin } \\
\text { order }\end{array}$} \\
\hline & & 2 & $75 / 25$ & \\
\hline & & 3 & $50 / 0$ & \\
\hline & & 4 & $25 / 75$ & \\
\hline & & 5 & $00 / 100$ & \\
\hline
\end{tabular}

\section{Results}

Total ninety participants were studied who were selected purposively. Respondent's sociodemographic profiles were depicted in Table 1.

Table 1 Respondents socio-demographic profile

\begin{tabular}{|c|c|c|}
\hline Characteristics & Frequency & Percentage \\
\hline \multicolumn{3}{|l|}{ Age (years) } \\
\hline Up to 40 & 2 & 2.2 \\
\hline $41-60$ & 72 & 80.0 \\
\hline $61-75$ & 16 & 17.8 \\
\hline \multicolumn{3}{|c|}{ Mean $( \pm$ SD) $54.60( \pm 7.414)$ years } \\
\hline \multicolumn{3}{|c|}{ Sex } \\
\hline Male & 83 & 92.2 \\
\hline Female & 7 & 7.8 \\
\hline \multicolumn{3}{|l|}{ Occupation status } \\
\hline Unemployed & 08 & $8.9 \%$ \\
\hline Service & 35 & $38.9 \%$ \\
\hline Business & 08 & $8.9 \%$ \\
\hline Retired & 39 & $43.3 \%$ \\
\hline \multicolumn{3}{|l|}{ Religion } \\
\hline Islam & 86 & 95.6 \\
\hline Hindu & 4 & 4.4 \\
\hline \multicolumn{3}{|l|}{ Educational status } \\
\hline Illiterate & 1 & $1.1 \%$ \\
\hline Class I to Class VIII & 13 & $14.4 \%$ \\
\hline Class IX to SSC & 25 & $27.8 \%$ \\
\hline HSC & 25 & $27.8 \%$ \\
\hline Degree and above & 19 & $21.1 \%$ \\
\hline \multicolumn{3}{|l|}{ Marital Status } \\
\hline Married & 87 & 96.7 \\
\hline Widow & 2 & 2.2 \\
\hline Wifeless & 1 & 1.1 \\
\hline \multicolumn{3}{|l|}{ Monthly income } \\
\hline$<10000$ & 29 & 32.2 \\
\hline $10000-30000$ & 53 & 58.9 \\
\hline 30000200000 & 7 & 7.8 \\
\hline$>50000$ & 1 & 1.1 \\
\hline \multicolumn{3}{|c|}{ Mean $( \pm$ SD) $18,127.78( \pm 22017.7<$} \\
\hline \multicolumn{3}{|c|}{ Family size ts } \\
\hline $1-3$ & 1 & 1.1 \\
\hline $4-6$ & 42 & 46.7 \\
\hline$>6$ & 47 & 52.2 \\
\hline Total & 90 & 100.0 \\
\hline Mean $( \pm$ SD) $4.57( \pm 1$ & & \\
\hline
\end{tabular}


AKMMC J 2013: 4(2)

Perceptions of QOL amongst CABG patients were calculated for all components and the two summary scores for physical health and mental health is presented in Table 2 .

Table 2 Distribution of different scores of quality of life

\begin{tabular}{lcccc}
\hline & Minimun & $\begin{array}{c}\text { Maximu } \\
\mathrm{m}\end{array}$ & Mean & SD \\
Physical & 48.81 & 100.00 & 84.91 & \pm 11.1 \\
Component & & & & \\
Score & & & & \\
Mental & 47.14 & 100.00 & 87.85 & $\pm 10 .$. \\
Component & & & & \\
Score & & & & \\
\hline $\begin{array}{l}\text { Total } \\
\text { Quality of }\end{array}$ & 48.14 & 100.00 & 86.09 & \pm 9.9 \\
Life & & & & \\
\end{tabular}

The mean for each SF-36 subscales, physical domains and mental domains were classified into level of poor QOL with the score of 0-49 and good level of QOL with the score of 50100. Results of this study revealed that post CABG patients in $\mathrm{CMH}$, Dhaka were reported to have good QOL. It was found that the association between age and physical functioning domain of physical component was statistically significant $\left(r=-.189^{*}, \mathrm{p}<0.05\right)$ and association between all other domains were statistically not significant (Table 3).

Table 3 Correlation between different domains of quality of life and age

\begin{tabular}{lll}
\hline Domain & Co -efficient $(\mathrm{r})$ & P value \\
\hline Physical & $-.189{ }^{*}$ & .037 \\
functioning & & \\
\hline Role physical & -.074 & .245 \\
\hline Bodily pain & -.062 & .279 \\
\hline General health & -.142 & .091 \\
\hline Vitality & .023 & .415 \\
\hline Social functioning & -.169 & .056 \\
\hline Role emotional & -.116 & .138 \\
\hline Mental health & .022 & .420 \\
\hline
\end{tabular}

The study also revealed a negative correlation of total quality of life with age but positive correlation with other socio demographic characteristics though all of the relations were statistically not significant. (Table 4)
SMN Irfan, M Rahman, A Noman et al

Table 4 Correlation between different socio demographic characteristics with total quality of life.

\begin{tabular}{lcc}
\hline \multicolumn{1}{c}{ Domain } & Co -effic ient $(\mathrm{r})$ & $\mathrm{p}$ value \\
\hline Age & -.024 & .410 \\
\hline Monthly income & .040 & .355 \\
\hline Education & .104 & .164 \\
\hline Occupation & .077 & .234 \\
\hline
\end{tabular}

In regards to the monthly income, highest score noted in Tk. 10000-30000 income groups in all the domains (Table-5).

Table 5 Distribution of monthly income of the respondents with various domains of quality of life

\begin{tabular}{|c|c|c|c|c|c|c|}
\hline Domains & Monthly income & $n$ & Mean & SD & $\mathrm{F}$ & $P$ value \\
\hline $\begin{array}{l}\text { Physical } \\
\text { functioning }\end{array}$ & $\begin{array}{l}<10000 \\
10000-30000 \\
30000-200000\end{array}$ & $\begin{array}{l}29 \\
53 \\
8\end{array}$ & $\begin{array}{l}\text { score } \\
867.24 \\
912.26\end{array}$ & $\begin{array}{l}124.840 \\
97.520 \\
124.642\end{array}$ & 1.614 & .205 \\
\hline $\begin{array}{l}\text { Role } \\
\text { physical }\end{array}$ & $\begin{array}{l}<10000 \\
10000-30000 \\
30000-200000\end{array}$ & $\begin{array}{l}29 \\
53 \\
8\end{array}$ & $\begin{array}{l}324.14 \\
294.34 \\
300.00\end{array}$ & $\begin{array}{l}127.210 \\
139.249 \\
160.357\end{array}$ & .446 & .642 \\
\hline Bodily pain & $\begin{array}{l}<10000 \\
10000-30000 \\
30000-200000\end{array}$ & $\begin{array}{l}29 \\
53 \\
8\end{array}$ & $\begin{array}{l}177.76 \\
184.06 \\
175.00\end{array}$ & $\begin{array}{l}29.447 \\
24.535 \\
46.599\end{array}$ & .666 & .516 \\
\hline $\begin{array}{l}\text { General } \\
\text { health }\end{array}$ & $\begin{array}{l}<10000 \\
10000-30000 \\
30000-200000\end{array}$ & $\begin{array}{l}29 \\
53 \\
8\end{array}$ & $\begin{array}{l}389.66 \\
404.25 \\
431.88\end{array}$ & $\begin{array}{l}71.501 \\
80.224 \\
79.639\end{array}$ & .985 & .378 \\
\hline Vitality & $\begin{array}{l}<10000 \\
10000-30000 \\
30000-200000\end{array}$ & $\begin{array}{l}29 \\
53 \\
8\end{array}$ & $\begin{array}{l}347.59 \\
355.09 \\
357.50\end{array}$ & $\begin{array}{l}45.799 \\
56.283 \\
75.166\end{array}$ & .206 & .815 \\
\hline $\begin{array}{l}\text { Social } \\
\text { functioning }\end{array}$ & $\begin{array}{l}<10000 \\
10000-30000 \\
30000-200000\end{array}$ & $\begin{array}{l}29 \\
53 \\
8\end{array}$ & $\begin{array}{l}188.79 \\
195.75 \\
193.75\end{array}$ & $\begin{array}{l}27.211 \\
16.796 \\
17.678\end{array}$ & 1.053 & .353 \\
\hline $\begin{array}{l}\text { Role } \\
\text { emotional }\end{array}$ & $\begin{array}{l}<10000 \\
10000-30000 \\
30000-200000\end{array}$ & $\begin{array}{l}29 \\
53 \\
8\end{array}$ & $\begin{array}{l}234.48 \\
216.98\end{array}$ & $\begin{array}{l}97.379 \\
115.585 \\
75.593\end{array}$ & 1.947 & .149 \\
\hline $\begin{array}{l}\text { Mental } \\
\text { health }\end{array}$ & $\begin{array}{l}<10000 \\
10000-30000 \\
30000-200000\end{array}$ & $\begin{array}{l}29 \\
53 \\
8\end{array}$ & $\begin{array}{l}150.00 \\
462.76 \\
470.19 \\
462.50\end{array}$ & $\begin{array}{l}47.426 \\
46.181 \\
58.979\end{array}$ & .268 & .766 \\
\hline
\end{tabular}

Respondents' occupation showed significant difference with the general health domain $(\mathrm{F}=$ $3.456, \mathrm{p}<0.05)$ and physical component summary $(\mathrm{F}=2.969, \mathrm{p}<0.05)$ of the SF- 36 items (Table-6). 
Health Related Quality of Life Among Coronary Artery Bypass

Table 6. Distribution of occupation of the respondents with different domains of quality of life

\begin{tabular}{|c|c|c|c|c|c|c|}
\hline Domains & Occupation & $n$ & Mean score & SD & $\mathrm{F}$ & $P$ value \\
\hline $\begin{array}{l}\text { Physical } \\
\text { functioning }\end{array}$ & $\begin{array}{l}\text { Unemployed } \\
\text { Service } \\
\text { Business } \\
\text { Retired }\end{array}$ & $\begin{array}{l}8 \\
35 \\
8 \\
39\end{array}$ & $\begin{array}{l}825.00 \\
917.14 \\
943.75 \\
880.77\end{array}$ & $\begin{array}{l}138.873 \\
93.889 \\
67.810 \\
117.885\end{array}$ & 2.398 & .074 \\
\hline $\begin{array}{l}\text { Role } \\
\text { physical }\end{array}$ & $\begin{array}{l}\text { Unemployed } \\
\text { Service } \\
\text { Business } \\
\text { Retired }\end{array}$ & $\begin{array}{l}8 \\
35 \\
8 \\
39\end{array}$ & $\begin{array}{l}187.50 \\
314.29 \\
287.50 \\
323.08\end{array}$ & $\begin{array}{l}180.772 \\
128.665 \\
180.772 \\
115.762\end{array}$ & 2.411 & .072 \\
\hline Bodily pain & $\begin{array}{l}\text { Unemployed } \\
\text { Service } \\
\text { Business } \\
\text { Retired }\end{array}$ & $\begin{array}{l}8 \\
35 \\
8 \\
39\end{array}$ & $\begin{array}{l}181.25 \\
184.43 \\
195.00 \\
175.51\end{array}$ & $\begin{array}{l}37.961 \\
23.097 \\
9.258 \\
32.400\end{array}$ & 1.314 & .275 \\
\hline $\begin{array}{l}\text { General } \\
\text { health }\end{array}$ & $\begin{array}{l}\text { Unemployed } \\
\text { Service } \\
\text { Business } \\
\text { Retired }\end{array}$ & $\begin{array}{l}8 \\
35 \\
8 \\
39\end{array}$ & $\begin{array}{l}384.38 \\
400.00 \\
481.25 \\
391.15\end{array}$ & $\begin{array}{l}44.194 \\
88.700 \\
25.877 \\
70.845\end{array}$ & 3.456 & .020 \\
\hline Vitality & $\begin{array}{l}\text { Unemployed } \\
\text { Service } \\
\text { Business } \\
\text { Retired }\end{array}$ & $\begin{array}{l}8 \\
35 \\
8 \\
39\end{array}$ & $\begin{array}{l}362.50 \\
344.57 \\
387.50 \\
351.28\end{array}$ & $\begin{array}{l}29.155 \\
68.614 \\
23.755 \\
46.293\end{array}$ & 1.465 & .230 \\
\hline $\begin{array}{l}\text { Social } \\
\text { functioning }\end{array}$ & $\begin{array}{l}\text { Unemployed } \\
\text { Service } \\
\text { Business } \\
\text { Retired }\end{array}$ & $\begin{array}{l}8 \\
35 \\
8 \\
39\end{array}$ & $\begin{array}{l}200.00 \\
196.43 \\
200.00 \\
187.82\end{array}$ & $\begin{array}{l}.000 \\
17.302 \\
.000 \\
26.203\end{array}$ & 1.764 & .160 \\
\hline $\begin{array}{l}\text { Role } \\
\text { emotional }\end{array}$ & $\begin{array}{l}\text { Unemployed } \\
\text { Service } \\
\text { Business } \\
\text { Retired }\end{array}$ & $\begin{array}{l}8 \\
35 \\
8 \\
39\end{array}$ & $\begin{array}{l}175.00 \\
211.43 \\
250.00 \\
223.08\end{array}$ & $\begin{array}{l}138.873 \\
113.167 \\
106.904 \\
98.573\end{array}$ & .712 & .547 \\
\hline $\begin{array}{l}\text { Mental } \\
\text { health }\end{array}$ & $\begin{array}{l}\text { Unemployed } \\
\text { Service } \\
\text { Business } \\
\text { Retired }\end{array}$ & $\begin{array}{l}8 \\
35 \\
8 \\
39\end{array}$ & $\begin{array}{l}470.00 \\
459.43 \\
497.50 \\
467.18\end{array}$ & $\begin{array}{l}38.545 \\
58.105 \\
7.071 \\
41.164\end{array}$ & 1.437 & .238 \\
\hline
\end{tabular}

The education level showed significant difference with the physical functioning of physical component domain $(\mathrm{F}=2.675, \mathrm{p}$ $<0.05)$. The findings showed that the highest score was for HSC education in both the components of quality of life (Table -7).
Table 7: Distribution of various domains of quality of life with education

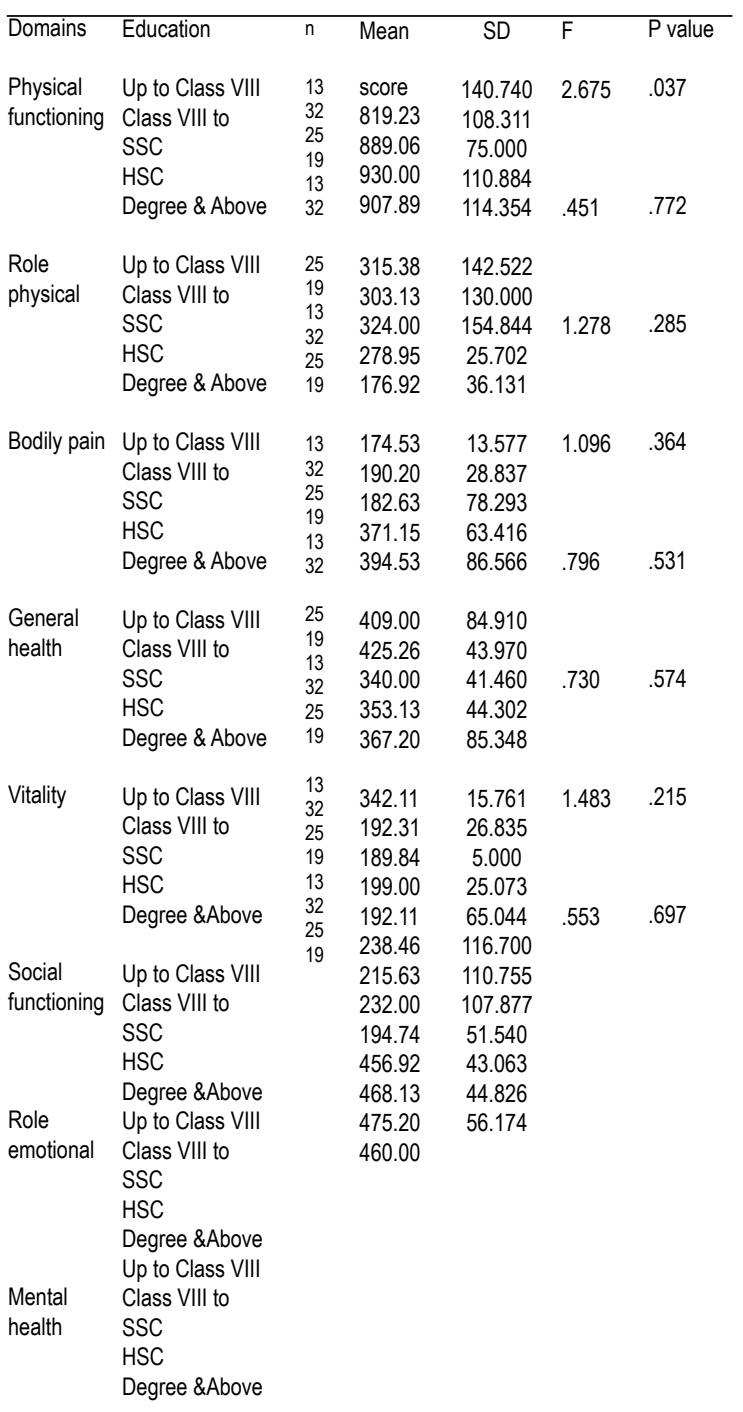

\section{Discussion}

Among 90 patients, majority, $72(80 \%)$ were in the age group of $41-60$ years followed by 16 $(17.8 \%)$ were within $61-75$ years and rest 2 $(2.2 \%)$ were within below 40 years age group. Mean age of the patients were 54.60 years. This clearly indicates that the coronary artery disease 
15 AKMMC J 2013: 4(2)

is associated with older group of patients. A study was carried out at BIRDEM hospital by Ahmed $\mathrm{G} \mathrm{U}$ et $\mathrm{al}^{9}$ which reflected that highest frequency of patients was in the age group of 40-49 which is almost similar to this study. This study finding was also similar to the study finding observed in a study by Islam $\mathrm{M} \mathrm{Z}$ et $\mathrm{al}^{10}$. where the mean age for coronary artery disease were between 40-60 years. According to BBS 2010 findings ${ }^{11}$, about $12 \%$ of the populations were within the age group of 45-59 years which differ with present study findings. It may be summarized from the study that regarding age most of the respondents were within the risk group of coronary artery diseases and accordingly operated surgically for complete cure.

This study revealed that majority of the patients i.e. $83(92.2 \%)$ were males and $07(7.8 \%)$ was females. A study was carried out regarding quality of life of CABG operation in elderly people by Efstratios A et al ${ }^{12}$ which revealed that females were minority for coronary disease which is similar to this study. Basing in facts, that this study was conducted at combined military hospital where most respondent were army population and sample was taken conveniently. So there were variations between these studies regarding sex.

It was evident from the study that $95.6 \%$ of respondents were Muslims and $4.4 \%$ were Hindu. It does not corresponds with BBS findings $2011^{13}$ where it was shown that the religion of people in Bangladesh was $89.6 \%$ Muslim, 9.3\% Hindus and rest $0.2 \%$ were others. This difference may be due to small sample size.

Regarding marital status of the patients, most of them, 87 (96.7\%) were married, $2(2.2 \%)$ were widow and $1(1.1 \%)$ were wifeless. In a study on the prevalence of coronary artery diseases and its relationship between gender, urbanization, education, marital status and occupation in the Iranian population conducted by Azimi-Nezhad $\mathrm{M}$ et al. ${ }^{14}$ showed that marital status was not significantly related to CAD.
SMN Irfan, M Rahman, A Noman et al

Moreover 97\% married respondents does not accord with BBS findings 2011 where it was shown that marriage rate for age group 40 - 60 years in Bangladesh was $97.68 \% 15$. In this study $80 \%$ respondents were more than 40 years aged and all of them were either service holder or retired, so most of the respondents were married.

In this study it was found that out of all the patients, majority i.e. 32 (35.6\%) were educated between class VIII to SSC level, while 25 (27.8\%) were in HSC level, 19 (21.1\%) were in Degree and above and 13 (14.4\%) were up to class VIII level qualified. It does not accorded with the preliminary census report of 2011 where literacy rate for Bangladeshi adult population was shown about $57.9 \% 16$.

As per profession, majority $39(43.3 \%)$ were retired, 35 (38.9\%) service holders, 08 (8.9\%) were business man and $08(8.9 \%)$ of them was unemployed. It was observed from the occupational findings that, prevalence of coronary artery diseases were more among them who were less exposed to physical activities. Julie $\mathrm{E}$ et a ${ }^{17}$ conducted a study on Occupation and Risk of Death From Coronary Heart Disease. The study revealed that there were significant relationship with occupation and coronary heart disease. Mark A. et al conducted another study named job strain and prevalence of coronary heart disease which also revealed a significant association between occupational pattern and coronary heart disease ${ }^{18}$.

In this study it was observed that $59 \%$ were in there income between 10000-30000, 32.2\% were income group (Tk. <10000) and the remaining $9 \%$ were in high income group (>Tk.30000). The average income was Tk. $18,127.78$ which is higher than average monthly household income (Tk. 11,480) ${ }^{16}$.

The result of this study showed that post CABG patients in cardiovascular surgery department of combined military hospital Dhaka have good quality of life. The mental components score $(87.8571 \pm 10.39988)$ was found to be higher than physical component score $(84.9153$ 
$\pm 11.69414)$. This is may be due to the fact that after CABG operation, the coronary artery diseased person becomes free from the physical difficulties, chest pain and all other parameter of life and have a sense of mental satisfaction with a sense of relieved from fear of impending death. This finding is similar to a study conducted by Ho SE et al, (2010) on "Quality Of Life amongst Post Coronary Artery Bypass Patients at the National Heart Institute, Malaysia" in the year 20108 who also revealed better scores for mental component of quality of life.

Positive relation with physical component may be due to the fact that educated person maintains their life style and health related behavior as per the advice then the poorly educated person. In case of physical functioning domains of physical components of quality of life, the result showed a statistically significant difference among the mean scores of different education groups. This finding was not commensurate with the findings of a study conducted by Ho SE et al, (2010) on "Quality Of Life amongst Post Coronary Artery Bypass Patients at the National Heart Institute, Malaysia" in the year $2010^{8}$ who revealed a significant difference with the general health domains of physical component of SF-36 items. They also found that respondents with tertiary education (degree and above) possessed the highest score followed by primary education and lastly secondary education.

The study revealed that most respondents quality of life improves after CABG operation and similar results were found by LeGrand et al $(2006)^{19}$. Similar result also revealed by a study conducted at Australia by Anastasios Merkouris et $\mathrm{al}^{37}$ on Quality of Life after Coronary Artery Bypass Graft Surgery in the Elderly who found that significant improvements in quality of life (80.4\%) 12 months after CABG operation? ${ }^{7}$. Good quality of life after CABG surgery also revealed by Everard W. et al who conducted a study on Quality of life outcomes after coronary artery bypass graft surgery: Relationship to neuropsychological deficit ${ }^{20}$.

\section{Conclusion}

The depicted results and discussion clearly indicate that quality of life among the coronary artery bypass graft operated patients is very important. It is evident that the incidence of non communicable disease as well as coronary artery diseases increasing very rapidly and coronary artery bypass graft operation is one of the definitive treatments for the person suffering from coronary artery disease.

The post CABG respondents possessed a good level of QOL with good mental components score than physical component score. It is also revealed from the study that with increasing age the physical functioning of the patient decreases. From the study it depicts that higher education, better occupation and good monthly income of the respondents have better quality of life out come than that of others.

\section{References}

1. The World Health Report. Neglected Global Epidemic: three growing threat, shaping the future. World health Organization, Geneva, 2003; 85-99.

2. What is Coronary artery Bypass Graft; National heart, lung and blood institute; US department of health and human service; February 23, 2012; http://www.nhlbi.nih.gov/

3. Bangladesh health Bulletine-2011; Director General of Health Service; Govt. of the people's republic of Bangladesh; January 6, 2012; 115.

4. Ware JE, Snow KK, Kosinski M, Gandek, B. SF-36 Health Survey. Manual and interpretation guide. Boston: The Health Institute, New England Medical Center, 1993

5. Ferachi, Kellye A; Physical Function and Quality of Life in the Very- and Oldest-Old: Gender Differences; thesis of Louisiana State University Agricultural and Mechanical College; www.etd.lsu.edu/docs/available/etd-0709103$132756 / . . . /$ Ferachi_thesis.pdf

6. Brazier JE, Walters SJ, Nicholl JP, Kohler B. Using the SF-36 and Euro Qol on an elderly population. Quality of Life Research 1996; 5: 195-204.

7. Anastasios Merkouris et al.; Quality of Life after Coronary Artery Bypass Graft Surgery in the Elderly; Eur J Cardiovasc Nurs, March 2009; vol. 8, 1: pp. 74-81. 
8. Ho SE, et al; Quality Of Life amongst Post Coronary Artery Bypass Patients at the National Heart Institute, Malaysia; Journal of Med and Health 2010; 5 (2); 77-85.

9. Ahmed G U, Zafrul H, Ataharul M I and Khan A K A; characteristics of the diabetes subject: BIRDEM Diabetes Registry 1985, Journal of Diabetic Association of Bangladesh, 1994; 22(2): 39-51.

10. Ziaul Islam M. and Mansur Ahmed MSA; Burden of Type $2 \mathrm{DM}$ among the patients attending outpatient department of BIRDEM hospital, Dhaka: Journal of Preventive \& Social Medicine, June 2008; 27(1): 17-29.

11. Statistical pocket book of Bangladesh 2010, Bangladesh Bureau of statistics, statistics division. Ministry of planning. Government of people's republic of Bangladesh, 2010.

12. Efstratios A et al.; Quality of Life after Coronary Artery Bypass Graft Surgery in the Elderly; Eur J Cardiovasc Nurs, March 2009; 8(1): 74-81.

13. Statistical pocket book of Bangladesh 2011, Bangladesh Bureau of statistics, statistics division. Ministry of planning. Government of people's republic of Bangladesh, 2011.
14. Azimi-Nezhad M, Ghayour-Mobarhan M, Parizadeh M R, Safarian M, Esmaeili H, Parizadeh S M J, et al. Prevalence of type 2 diabetes mellitus in Iran and its relationship with gender, urbanization, education, marital status and occupation, Original Article: Singapore medical journal 2008; 49(7): 571.

15. Population Census 2011, Preliminary report, Bangladesh Bureau of statistics, statistics division. Ministry of planning. Government of people's republic of Bangladesh.

16. Bangladesh Health Bulletins 2011; Director General of Health service, Ministry of Health and Family Welfare; Government of bangladesg.

17. Julie E et al. Occupation and risk of death from Coronary Heart Diseases; Journal of American Medical Association; 1987; 258 (b); 791-792.

18. Mark et al. Job Strain and the Prevalence and out come of coronary artery diseases; American Heart Association Journal 1995; 93: 327-333.

19. LeGrand et al. Health related Quality of life trajectories and predictories following Coronary Artery Bypass Graft surgery; Health and quality of life out comes, 2006; 4(49): 1; 186-1477.

20. Everard W et al. Quality of Life out come after coronary artery bypass graft surgery; The Journal of thoracic and cardiovascular surgery 2005; 130: 1022-1027. 